\title{
CROSS-BORDER COOPERATION ON SECURITY IN EUROPE
}

\author{
EMILIA BOGACKA \\ Adam Mickiewicz University, Institute of Socio-Economic Geography and Spatial Management, Poznań, \\ Poland
}

Manuscript received July 30, 2010

Revised version November 23, 2010

Bogacka E., Cross-border cooperation on security in Europe. Quaestiones Geographicae 29(4), Bogucki Wydawnictwo Naukowe, Poznań 2010, pp. 41-51, 5 figs, 4 tables. DOI 10.2478/v10117-010-0030-5, ISBN 978-83-62662-30-2, ISSN 0137-477X.

AвSTRACT: The aim of the article is to present cross-border cooperation on security. For this purpose, various problems in the European Union with respect to criminal policy must be described. The article consists of three parts. The first presents selected European institutions established to prevent and fight crime. The second concentrates on the control of external EU borders, quoting people's opinions on this matter and describing one of the EU programmes, the European Neighbourhood \& Partnership Instrument: Cross-Border Cooperation. The third part focuses on security of the Polish borders as those which in recent years have witnessed serious political changes - Poland's accession to the European Union and the Schengen zone. The paper finishes with conclusions.

KEY WORDS: cross-border cooperation, security policy, Europe

Emilia Bogacka, Institute of Socio-Economic Geography and Spatial Management, Adam Mickiewicz University, ul. Dzięgielowa 27, 61-680 Poznań, Poland; e-mail: ebogacka@amu.edu.pl

\section{Introduction}

Crime, along with unemployment, the economic situation, inflation, and health care system, is one of the most important issues facing all the European countries (Standard Eurobarometer 72, 2009). The European Security Strategy (2003) pointed out that "As a union of 25 states with over 450 million people producing a quarter of the world's Gross National Product, the European Union is inevitably a global player. [...] Europe should be ready to share in the responsibility for global security and in building a better world." The strategy emphasizes that "No single country is able to tackle today's complex problems on its own", because global security is a state to reach only by the cooperation of all European coun- tries. According to the document, the European Union has three strategic objectives in defending its security and promoting its values: 1) addressing the threats, 2) building security in our neighbourhood, and 3) building an international order based on effective multilateralism.

The security of border areas has a special meaning, especially taking into consideration the fact that a border can be defined as a line marking "the limits of executive police powers, (and) states are reluctant to loosen their grip on these powers since territorial sovereignty represents an important political and psychological threshold for any European country" (Anderson et al. 1995). Crime in border areas has been a subject of much research, not only in Europe (de Ruyver et al. 1993, van Duyne 1993, Jamieson 1999, Gay- 
lord 1999, Junninen \& Aromaa 2000, Ceccato \& Haining 2004, Guerette \& Clarke 2005, Orrenius \& Coronado 2005, Albuquerque 2007). The conclusion of all the studies are best stated by Ceccato \& Haining (2004): "Political borders and the areas close to them are unique places for criminal activities." They also distinguish, on the basis of literature, eight factors, grouped by type, that make border regions susceptible to crime (for a full description of the distinguished factors see Ceccato \& Haining 2004): a) those related to the location and geography: border's regional position, border type (length, landscape, adjacency of land, sea or bridge); b) those related to societal structures and organizational differences: economic inequality and relative deprivation between neighbouring countries; cultural differences and gender inequality; weakened state apparatus and political and social instability; differences in taxation, tariffs and regulations; differences in law and law enforcement and lack of harmonization of criminal justice/legislation; and c) those related to conditions for criminal activity: symbiosis between cross-border and other forms of crime; offender's knowledge and perception of the border.

All the distinguished factors are strengthened by political changes taking place in Europe, especially the Schengen zone enlargements. Therefore security of external borders is of great importance to the whole of the European Union.

The aim of the paper is to present cross-border cooperation on security in Europe. The structure of this article is as follows. It begins with the presentation of selected European institutions established to prevent and fight crime. The second part concentrates on the control of external EU borders, as the problems of the European Union's neighbours pose problems for Europe. The European Neighbourhood \& Partnership Instrument: Cross-Border Cooperation programmes are presented, especially their security-related priorities. The last section focuses on the security of the Polish borders. The paper finishes with conclusions.

\section{European response to security issues}

European citizens treat security as a common issue and reckon that the role of the European Union in ensuring that security should have fundamental importance. According to a research (Special Eurobarometer 290, 2008), people's support for decision making in the field of security at a European level is relatively high. The respondents support:

- fight against organized crime and trafficking $-81 \%$;

- fight against terrorism - $81 \%$;

- exchange of police and judicial information between Member States - 76\%;

- fight against drug abuse - 75\%;

- promoting and protecting fundamental rights, including children's rights $-72 \%$;

- control of external borders of the EU - 70\%;

- asylum and migration policy $-63 \%$.

There are several institutions in Europe established to prevent and fight crime in different ways. This part gives an overview of the activity of selected European institutions: the European Police Office, Eurojust, European Police College, Frontex, European Network and Information Security Agency, European Crime Prevention Network, and European Institute for Crime Prevention and Control.

The European Police Office (Europol), established in 1999 and located in The Hague (The Netherlands), is a law enforcement agency ${ }^{1}$. Its main goal is to prevent and combat terrorism, drug trafficking and other forms of organized crime. Europol workers not only cooperate with the EU member countries, but also with the USA, Canada, Australia and Norway.

Eurojust, set up in 2002 and located in The Hague (The Netherlands), is a judicial agency formed to fight serious crime ${ }^{2}$. It seeks to achieve it by coordinating action for investigations and prosecutions which take place in more than one EU member country. The existence of Eurojust is essential due to the fact that European countries differ in law and law enforcement systems.

Another EU agency, the European Police College (CEPOL) was established in 2005 and is

www.europol.europa.eu/ (access 5 July 2010).

2 www.eurojust.europa.eu/index.htm (access 6 July 2010). 
headquartered in Bramshill (England) ${ }^{3}$. CEPOL supports European police officers' cross-border cooperation in their fight against crime and protection of public security as well as law and order. The agency organizes about 70-100 courses, seminars and conferences every year. CEPOL has 35 police colleges around Europe: in Austria (1), Belgium (1), Bulgaria (1), Cyprus (1), the Czech Republic (1), Denmark (1), Estonia (1), Finland (1), France (2), Germany (1), Greece (1), Hungary (1), Iceland (1), Ireland (1), Italy (1), Latvia (1), Lithuania (1), Luxembourg (1), Malta (1), Norway (1), Poland (5), Portugal (1), Romania (1), Slovakia (1), Slovenia (1), Spain (1), Sweden (1), Switzerland (1), The Netherlands (1), and the United Kingdom (1). Working together as a network allows identification and an exchange of good practice.

The main aim of Frontex, a European Union agency situated in Warsaw (Poland) established in 2005, is to help to control EU external borders. The tasks of the Frontex are the following4: 1) coordination of operational cooperation between EU members in the field of management of external borders, 2) assistance in the training of national border guards, including the establishment of common training standards, 3) carrying out risk analyses, 4) following up the development of research relevant for the control and surveillance of external borders, 5) assistance in circumstances requiring increased technical and operational assistance at external borders, and 6) providing the necessary support in organizing joint return operations.

Another European Union body, the European Network and Information Security Agency (ENISA), located in Heraklion (Greece), was established in $2004^{5}$. Its main aim is to make information secure, particularly online banking, e-commerce and mobile phones. Due to the fact that almost everyone uses a mobile phone, has an Internet bank account or just uses the Internet, security of their use is essential. Worth mentioning are new types of crime, for example identity

http:/ / www.cepol.europa.eu/ (access 6 July 2010).

4 According to the Frontex official website www.frontex.europa.eu (access 4 July 2010).

5 Information according to the European Network and Information Security Agency website www.enisa.europa.eu/ (access 5 July 2010). theft, which are becoming a growing problem nowadays. Taking into consideration that the Internet is the most globalized medium, securing it is of special importance.

The European Crime Prevention Network (EUCPN) was set up by the European Council decision in May 2001 in Vienna ${ }^{6}$. It has 27 members: Austria, Bulgaria, Belgium, Cyprus, the Czech Republic, Denmark, Estonia, Finland, France, Germany, Greece, Hungary, Ireland, Italy, Latvia, Lithuania, Luxembourg, Malta, The Netherlands, Poland, Portugal, Romania, Slovenia, Slovakia, Spain, Sweden, and the United Kingdom. The activity of the EUCPN is mostly concentrated on exchanging information between the members about good practice in crime prevention, facilitating cooperation, developing local and national strategies on crime prevention, and also on organizing meetings, seminars and conferences. The institution also funds the European Crime Prevention Award for the best crime prevention project. The award was won by Slovakia in 2004, The Netherlands in 2005, Denmark in 2006, Sweden in 2007, the United Kingdom in 2008, and the last one, in 2009, by Finland.

The European Institute for Crime Prevention and Control (HEUNI), affiliated with the United Nations, was established in 1981 in Helsinki (Finland) $)^{7}$. HEUNI links institutions operating within the framework of the United Nations Crime Prevention and Criminal Justice Programme. The institution aims at promoting exchange of information on crime prevention, especially by organizing seminars and expert group meetings. HEUNI also does research on crime statistics, victimization surveys, criminal justice systems, human trafficking, violence against women, prisons, and corruption. Publications on these topics are available on the website. The institution also grants short-time scholarships.

The presentation of the selected European institutions established to prevent and fight crime shows that most of their activity is concentrated on the theoretical background of crime prevention and fight against crime. Moreover, most of these institutions were established recently, at the beginning of the $21^{\text {st }}$ century. This is too short

6 www.eucpn.org/ (access 6 July 2010).

7 www.heuni.fi (access 7 July 2010). 
Table 1. Attitude of respondents to control of the external borders of the European Union.

\begin{tabular}{|c|c|c|c|c|c|}
\hline \multirow{2}{*}{\multicolumn{2}{|c|}{ Respondents }} & \multicolumn{4}{|c|}{$\begin{array}{l}\text { Do you believe that more or less decision-making about control of external } \\
\text { borders of the European Union should take place at a European level? }\end{array}$} \\
\hline & & More decision- & Less decision- & No change is & \\
\hline \multirow{2}{*}{ Sex } & Female & 69 & 15 & 7 & 9 \\
\hline & Male & 72 & 16 & 7 & 5 \\
\hline \multirow{4}{*}{ Age } & $15-24$ & 67 & 17 & 8 & 8 \\
\hline & $25-39$ & 74 & 14 & 6 & 6 \\
\hline & $40-54$ & 72 & 15 & 7 & 6 \\
\hline & $55+$ & 68 & 16 & 7 & 9 \\
\hline \multirow{8}{*}{$\begin{array}{l}\text { Respondent } \\
\text { occupation } \\
\text { scale }\end{array}$} & Self-employed & 74 & 15 & 6 & 5 \\
\hline & Managers & 73 & 15 & 7 & 5 \\
\hline & Other white collars & 73 & 15 & 7 & 5 \\
\hline & Manual workers & 71 & 16 & 7 & 5 \\
\hline & House persons & 69 & 15 & 6 & 10 \\
\hline & Unemployed & 69 & 16 & 7 & 8 \\
\hline & Retired & 68 & 16 & 7 & 9 \\
\hline & Students & 69 & 17 & 7 & 7 \\
\hline
\end{tabular}

Source: Special Eurobarometer 290, 2008.

a period of activity to attempt a full and appropriate assessment. Besides, none of the presented institutions publishes a full report of its activity, which hinders evaluation. Nevertheless, monitoring should be conducted.

\section{Control of EU external borders}

In this paper emphasis is put on security policy at the external borders of the European Union. On the one hand, European Union enlargements increase its members' security because membership means the protection of all the EU agencies taking care of security, but on the other they bring the Union closer to so-called trouble areas. External borders of the European Union are in danger. The first part of this chapter presents people's opinion on the control of EU external borders, and the second part describes one of the EU programmes, viz. the European Neighbourhood \& Partnership Instrument: Cross-Border Cooperation, as one concentrating also on security issues.

\subsection{Control of EU external borders in the light of Eurobarometer ${ }^{8}$ opinions}

People's opinions are very important when it comes to the field of security (Special Eurobarometer 290, 2008). Seven out of ten Europeans believe that decision-making on policies related to controlling external borders should take place at the European Union level. Only 16\% want less involvement, $7 \%$ think no change is needed and $7 \%$ lack an opinion. The answers given by different socio-economic groups of respondents are presented in Table 1. In general, the strong support for making decisions on policies related to the external borders of the European Union suggests that all initiatives on this issue are needed.

The survey shows that the support for more decision-making at a European level fluctuates from $49 \%$ in the United Kingdom to $82 \%$ in Cyprus and the Czech Republic (Fig. 1). In 13 countries the respondents' answers exceeded the European Union average and in 12 were below it. In Poland and Luxembourg the answers were at the same level as in the EU-27. It is worth under-

8 Eurobarometer is a publication of the Public Opinion Analysis Sector of the European Commission. All the publications can be found at http://ec.europa.eu/ public_opinion/index_en.htm. 


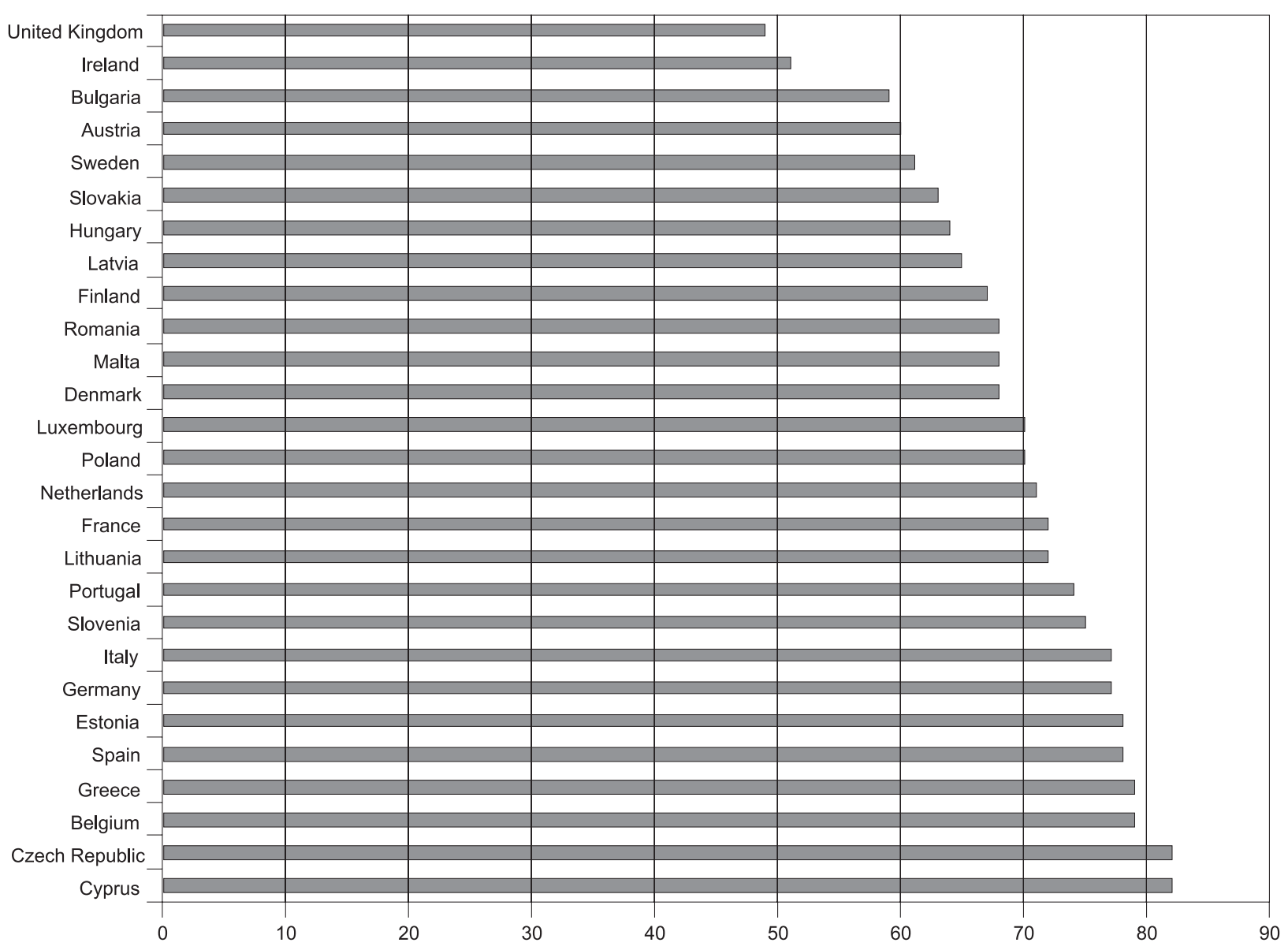

Fig. 1. Support for more decision-making at a European level about the control of external borders of the European Union: structure of answers by nationality of respondents. Source: Special Eurobarometer 290, 2008.

lining that the support for more decision-making at a European level was the lowest in two nonSchengen countries - the United Kingdom and Ireland.

\subsection{Control of EU external borders in the light of the European Neighbourhood \& Partnership Instrument: Cross-Border Cooperation}

The European Union pays special attention to its external borders and the possible problems related to them. Among the European Union programmes is the European Neighbourhood \& Partnership Instrument: Cross-Border Cooperation (ENPI CBC). Its main idea is cross-border cooperation on the external borders of the European Union. For the period 2007-2013, fifteen programmes have been established: 9 involving land borders; 3 , sea-crossing, and 3, sea-basins (Table 2).
According to the European Neighbourhood \& Partnership Instrument: Cross-Border Cooperation Strategy Paper 2007-2013, six specific common challenges in the transboundary context of ensuring efficient and secure borders can be distinguished. An integrated and harmonious regional development across the European Union border can help to balance disparities between the countries and deal with illegal migration flows and organized crime. Environmental issues are especially important in the sea basins (the Baltic Sea, the Black Sea and the Mediterranean), where water pollution and water shortage are serious problems. In a cross-border context also public health issues are significant, particularly in the case of communicable diseases, epidemic and pandemic diseases. The fight against organized crime is named a key cross-border challenge. Emphasis is put on cross-border cooperation in improving prevention and fight against organized crime, corruption and terrorism. European 
Table 2. European Neighbourhood \& Partnership Instrument: Cross Border Cooperation Programmes.

\begin{tabular}{|c|c|c|c|c|}
\hline Type & Name of programme & Countries & Million euros & $\begin{array}{l}\text { Improving se- } \\
\text { curity }\end{array}$ \\
\hline \multirow{9}{*}{$\begin{array}{l}\text { Land- } \\
\text { Border }\end{array}$} & Kolarctic-Russia & Finland, Norway, Russia, Sweden & 28.241 & $x$ \\
\hline & Karelia-Russia & Finland, Russia & 23.023 & $\mathrm{o}$ \\
\hline & South-East Finland-Russia & Finland, Russia & 36.185 & $x$ \\
\hline & Estonia-Latvia-Russia & Estonia, Latvia, Russia & 47.775 & $x$ \\
\hline & Latvia-Lithuania-Belarus & Belarus, Latvia, Lithuania & 41.737 & $x$ \\
\hline & Lithuania-Poland-Russia & Lithuania, Poland, Russia & 132.13 & o \\
\hline & Poland-Belarus-Ukraine & Belarus, Poland, Ukraine & 186.201 & $x$ \\
\hline & $\begin{array}{c}\text { Hungary-Slovakia-Roma- } \\
\text { nia-Ukraine }\end{array}$ & $\begin{array}{l}\text { Hungary, Romania, Slovakia, } \\
\text { Ukraine }\end{array}$ & 68.638 & $x$ \\
\hline & $\begin{array}{l}\text { Romania-Ukraine-Republic } \\
\text { of Moldova }\end{array}$ & $\begin{array}{l}\text { Romania, Republic of Moldova, } \\
\text { Ukraine }\end{array}$ & 126.718 & $x$ \\
\hline \multirow{3}{*}{$\begin{array}{l}\text { Sea-cross- } \\
\text { ing }\end{array}$} & Italy-Tunisia & Italy, Tunisia & 25.191 & $\mathrm{o}$ \\
\hline & Spain-Morocco & Morocco, Spain & 135.231 & o \\
\hline & CBC Atlantic & Morocco, Spain & 27.762 & $\mathrm{o}$ \\
\hline \multirow{3}{*}{ Sea-basin } & Black Sea & $\begin{array}{l}\text { Armenia, Azerbaijan, Bulgaria, } \\
\text { Georgia, Greece, Moldova, Roma- } \\
\text { nia, Russia, Turkey, Ukraine }\end{array}$ & 17.307 & o \\
\hline & Mediterranean Sea & $\begin{array}{l}\text { Algeria, Cyprus, Egypt, France, } \\
\text { Greece, Italy, Libya, Malta, Mo- } \\
\text { rocco, Portugal, Spain, Tunisia, } \\
\text { Turkey, United Kingdom }\end{array}$ & 173.607 & o \\
\hline & Baltic Sea Region & $\begin{array}{l}\text { Belarus, Denmark, Estonia, Fin- } \\
\text { land, Germany, Latvia, Lithuania, } \\
\text { Norway, Poland, Russia, Sweden }\end{array}$ & 22.608 & o \\
\hline
\end{tabular}

$\mathrm{x}$ - issue present, $\mathrm{o}$ - issue absent

Source: own elaboration on the basis of http://ec.europa.eu/europeaid/where/neighbourhood/regional-cooperation/enpi-cross-border/ index_en.htm (access 6 March 2010).

Union borders, especially external, need effective border management to ensure their efficiency (facilitating legal trade and transit) and security (preventing illegal trade and transit). The last challenge is people-to-people cooperation improving economic, social and cultural contacts between people on both sides of the border.

The ENPI CBC aims to: 1) promote economic and social development in regions on both sides of common borders, 2) address common challenges (in fields like the environment, public health, prevention and fight against organized crime), 3) ensure efficient and secure borders, and 4) promote local cross-border people-to-people actions.

In seven out of the fifteen programmes an emphasis is put on improving security (Table 2). Among them are only land-border types of programme, except for the Karelia-Russia and the Lithuania-Poland-Russia Programmes. The seacrossing and sea-basin types do not include any security priorities. Priorities referring to security in the seven ENPI CBC programmes are presented below.

\section{1) The Kolarctic-Russia Programme ${ }^{9}$}

According to the programme priorities, security is a foundation of all cross-border activities. It is underlined that ensuring safety of local citizens is necessary for safe location for industry and travellers. In order to secure movement of people and goods, harmonized border formalities and border-crossing procedures are the most important. This can be achieved by cooperation and exchange of best practice between border authorities and personnel (in particular border guards, customs), as well as investments assur-

9 On the basis of www.kolarcticenpi.info/ (access 6 March 2010). 
ing availability of modern technology to minimize border disadvantages.

\section{2) The South-East Finland-Russia Programme ${ }^{10}$}

Efficient and secure borders are one of the common challenges in South-East Finland and Russia. As the most important border-crossing points between Finland and Russia are located in South-East Finland, developing transportation links is especially significant. The objective of the priority is to improve traffic arrangements at border-crossing points and border procedures to increase the transparency and efficiency of goods trade and people movement. The following actions might be undertaken: 1) improving smallscale infrastructure projects at border-crossing points and their vicinity where appropriate, 2) improving equipment at border-crossing points as necessary, 3) promoting training and networking between border authorities, and 4) promoting cooperation of customs and control authorities to assure efficient and secure control and smoothly operating border-crossing points.

\section{3) The Estonia-Latvia-Russia Programme ${ }^{11}$}

Maintaining efficient and safe borders is only mentioned in this programme as part of the priority concerning socio-economic development. More emphasis is put on the development of the border region's competitiveness by supporting business and labour market development and improving communication networks as well as exploring its potential for tourism.

\section{4) The Latvia-Lithuania-Belarus Programme ${ }^{12}$}

Among common challenges of the three neighbouring countries are improvements in the infrastructure and equipment of border-crossing points, border management operations and customs procedures. These initiatives are to secure an attractive living environment and welfare for the inhabitants of the border region.

10 On the basis of www.southeastfinrusnpi.fi/ (access 6 March 2010).

11 On the basis of www.estlatrus.eu/ (access 6 March 2010).

12 On the basis of www.enpi-cbc.eu/ (access 6 March 2010).

\section{5) The Poland-Belarus-Ukraine Programme ${ }^{13}$}

According to the programme priorities, efficient and secure borders can be assured by an increase in the capacity of border-crossing points.

\section{6) The Hungary-Slovakia-Romania-Ukraine Programme ${ }^{14}$}

One of its priorities, which is an increased border efficiency, aims at increasing the efficiency of border management on the Ukrainian border. This can be achieved by improvement in bordercrossing transport infrastructure and border control.

\section{7) The Romania-Ukraine-Republic of Moldova Programme ${ }^{15}$}

The main aim of the programme is to improve the area's economic, social and environmental situation in terms of safe and secure borders through increased contact on both sides of the border. No specific actions are mentioned in the programme priorities.

Taking into consideration the fact that all measures taken in the ENPI CBC programmes are supposed to ensure efficient and secure borders, priorities referring to broadly understood security are not emphasized too strongly among their aims. Improvement in the infrastructure of border-crossing points cannot replace people's cooperation in the field of security. In fact, enhancing border security by e.g. an exchange of good practice is only stated explicitly in the Kolarctic-Russia Programme and the South-East Finland-Russia Programme.

\section{Security of the Polish borders}

The recent years have brought two very important political changes to Poland, namely accession to the European Union and the Schengen zone. Security issues related to the EU accession connected with the EU agencies have been dis-

13 On the basis of www.interreg.gov.pl/20072013/ instrument+sasiedztwa/pl-bl-uk/ (access 6 March 2010).

14 On the basis of www.huskroua-cbc.net/ (access 6 March 2010).

15 On the basis of www.ro-ua-md.net/ (access 6 March 2010). 


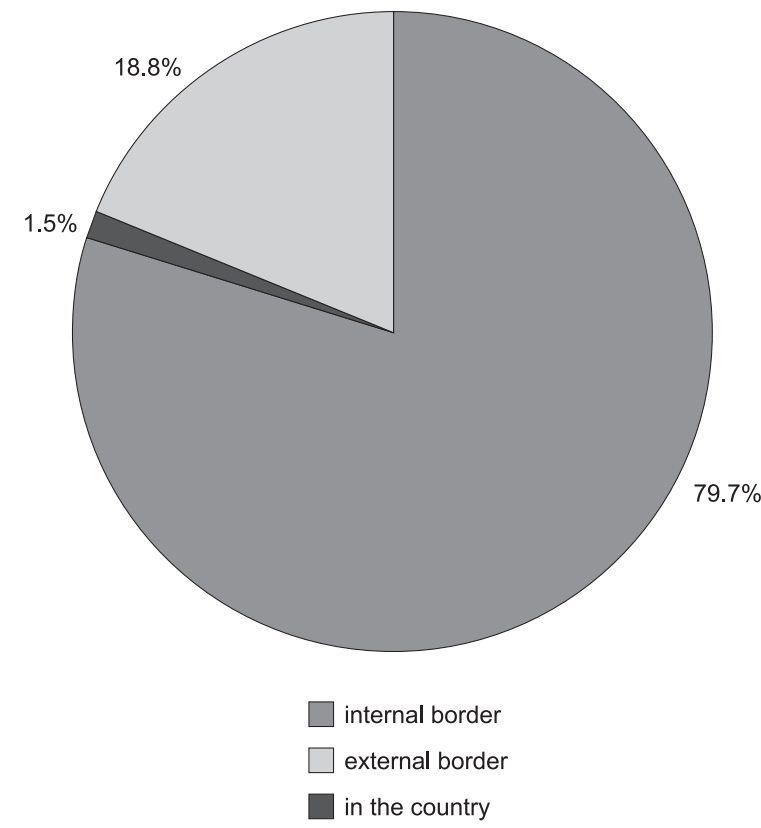

Fig. 2. Structure of illegal border crossings by type of border in Poland in 2004.

Source: own elaboration on the basis of Polish Border Guards statistics.

cussed earlier. This part concentrates on the consequences of Schengen zone membership for Poland.

The permeability of the Polish borders with Germany, the Czech Republic, Slovakia and Lithuania has changed as a consequence of joining the Schengen zone because the progressive integration of Europe allows free movement of people across the EU member countries. Lack of control at the borders has some implications for Poland in the field of security. The focus of this study is crime strictly related to the border: illegal crossings and illegal trade. Two years in particular will be taken into account: 2004 as the year of Poland's accession to the European Union and 2008 as the first year after the opening of Polish borders when some effects could possibly be seen ${ }^{16}$.

In 2004, when the movement was controlled on all the Polish borders, almost $80 \%$ of illegal border crossings occurred on the internal European Union border (Fig. 2). The situation changed dramatically in 2008 when almost $60 \%$ of illegal

16 Poland signed the agreement on 21st December 2007. Since then Polish road crossings with Germany, the Czech Republic, Slovakia and Lithuania have been open. Sea and air crossings have been open since 30th March 2008.

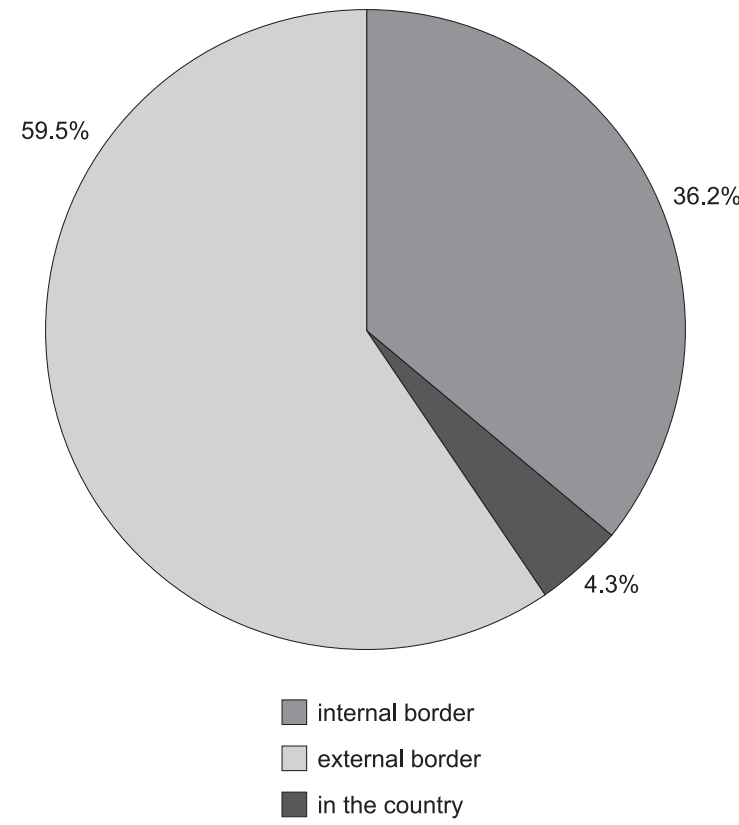

Fig. 3. Structure of illegal border crossings by type of border in Poland in 2008.

Source: own elaboration on the basis of Polish Border Guards statistics.

border crossings were reported from the external border (Fig. 3). It can be explained by the lack of control on the internal European Union border: more border guard forces where moved to the borders with Russia, Ukraine and Belarus, which strengthened control on the border crossings there and resulted in stopping more illegal migrants to the country. In both years illegal border crossings in the country (e.g. at airports) ${ }^{17}$ played a marginal role.

As Table 3 shows, the number of illegal border crossings increased slightly between the years 2004 and 2008. In 2004 their highest number was recorded at the borders with Germany and the Czech Republic ${ }^{18}$, almost four times as high as on the EU external border as a whole. As was mentioned before, when comparing the 2004 and 2008 figures, one can see the effect of the lack of control on the borders with Germany, the Czech Republic, Slovakia and Lithuania and strengthened control on the rest. For instance, the number

17 Border guards work not only strictly on the border. A list of places where border guards operate is available at www.strazgraniczna.pl/wps/portal.

18 The author believes that the relatively high number of illegal crossings of the border with the Czech Republic is due to the fact that people cross it unintentionally - it mostly runs in the mountains and might not be always visible. 
Table 3. Number of illegal border crossings by border type in Poland in 2004 and 2008.

\begin{tabular}{|c|r|r|}
\hline Border & $\mathbf{2 0 0 4}$ & $\mathbf{2 0 0 8}$ \\
\hline Russia & 62 & 72 \\
\hline Belarus & 72 & 469 \\
\hline Ukraine & 659 & 2,829 \\
\hline Sea & 77 & 12 \\
\hline Air & 215 & 70 \\
\hline Total external EU border & 1,085 & 3,452 \\
\hline Lithuania & 62 & 295 \\
\hline Slovakia & 231 & 523 \\
\hline Czech Republic & 1,131 & 709 \\
\hline Germany & 3,168 & 569 \\
\hline Total internal EU border & 4,592 & 2,096 \\
\hline In the country & 85 & 249 \\
\hline Total & 5,762 & 5,797 \\
\hline
\end{tabular}

Source: Polish Border Guards statistics.

of illegal border crossings on the border with Ukraine increased and on the border with Germany decreased radically. Illegal border crossings on the border with Russia, as well as on the

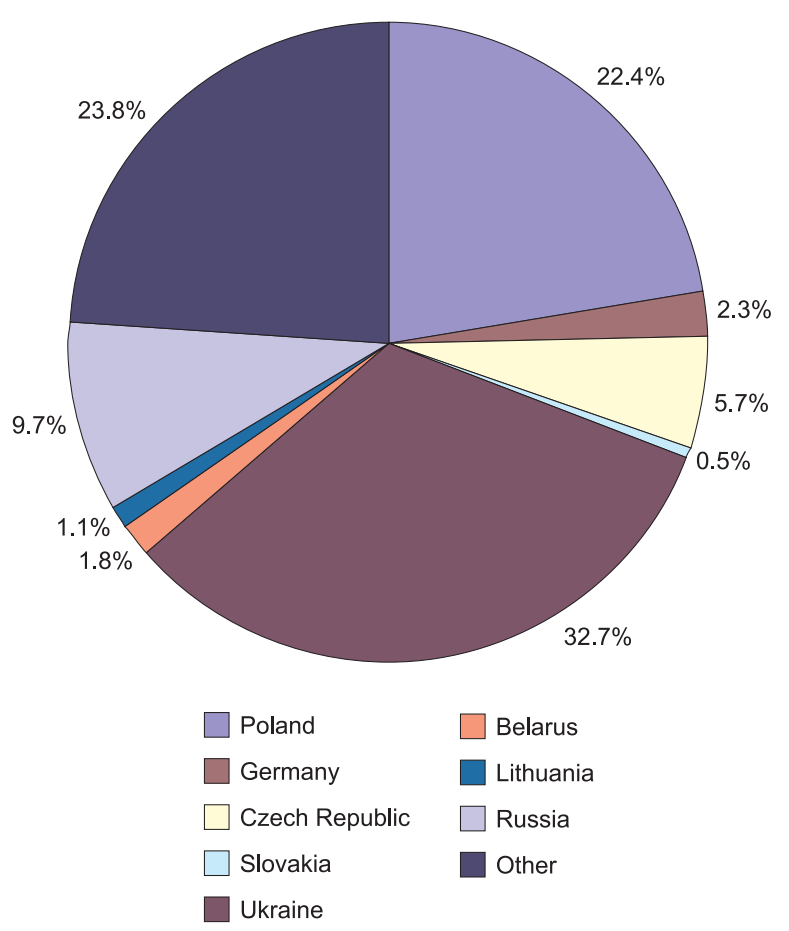

Fig. 4. Nationality structure of illegal border crossers in Poland in 2004.

Source: own elaboration on the basis of the Polish Border Guards statistics. sea and air borders, were of little significance for the total figure.

There is also a considerable change in the nationality structure of illegal border crossers (Figs 4 and 5). The share of Ukrainians, who were the most frequent illegal border crossers in both years, increased significantly. Taking into consideration Polish illegal migrants, a positive change took place: their proportion fell by almost $20 \%$, the highest decrease of all.

The other type of border-related crime, illegal trade, is a matter of essential importance for border safety. In the recent years the value of smuggled goods increased gradually to reach 150 million zlotys in 2008 (Table 4). More than $80 \%$ of this figure was accounted for by what the Polish Border Guards categorize as illegal "trading goods" (e.g. cigarettes, alcohol, foreign currency). The value of others goods (not listed in the table) was insignificant.

Good examples of cross-border cooperation on security can be found on the Polish-German border. The Polish-German Centre for Cooperation of Border Guards, Customs and Police located at Świecko (Poland) was established on 20

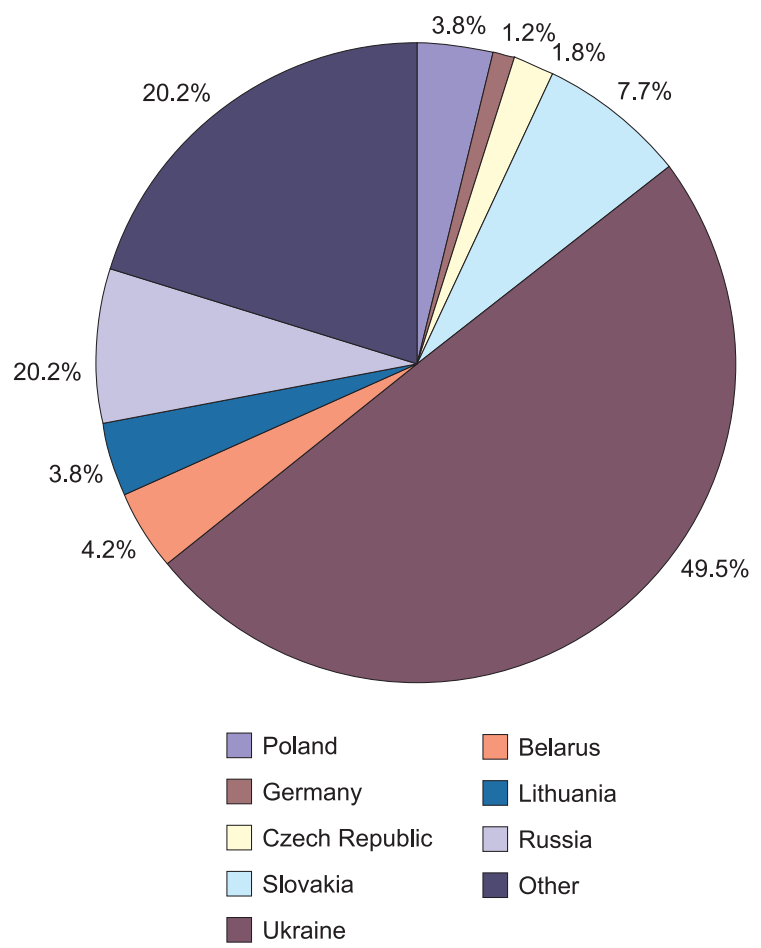

Fig. 5. Nationality structure of illegal border crossers in Poland in 2008.

Source: own elaboration on the basis of the Polish Border Guards statistics. 
Table 4. Value of illegal trade in Poland in the years 2004-2008 (in million zlotys).

\begin{tabular}{|c|c|c|c|c|}
\hline \multirow{2}{*}{ Year } & \multicolumn{4}{|c|}{ Value of smuggled good } \\
\cline { 2 - 5 } & Trading goods & Cars & Drugs & Total \\
\hline 2004 & 54.3 & 39.6 & 7.2 & 101.2 \\
\hline 2005 & 67.5 & 42.1 & 3.0 & 112.7 \\
\hline 2006 & 65.6 & 27.9 & 21.8 & 115.5 \\
\hline 2007 & 88.0 & 27.3 & 2.4 & 118.0 \\
\hline 2008 & 123.1 & 24.0 & 4.2 & 151.8 \\
\hline
\end{tabular}

Source: own calculations on the basis of Polish Border Guards statistics.

December 2007 under the Schengen agreement, a day before the opening of the Polish-German border. It is patterned on the first such centre in Europe - the one on the German-French border (Kiel - Strasbourg), and is the largest centre of cross-border cooperation on security in Europe. Its 63-strong staff includes 24 Poles (Police - 7, Customs - 7, Border Guards - 10) and 39 Germans (Federal Police - 21, Border Guards (Landespolizei) - 16, Customs - 2). The main aims of the centre's activity are to: 1) collect and exchange information, 2) assist in filling in application forms requiring information, 3 ) support and coordinate operations, 4) coordinate readmissions, and 5) support Polish-German cooperation.

\section{Conclusions}

The presented examples of cross-border cooperation on security prove the significance of security issues for Europe. The necessity for cross-border cooperation between European countries in this field is strengthened by the political changes: enlargements of the European Union and especially the Schengen zone.

The article leads to some conclusions:

(1) Since the European Union citizens support decision making in the field of security at a European level, the presented institutions established to prevent and fight crime are a proper European response to security issues. The institutions provide a legal framework and a possibility of exchanging good practice in cross-border cooperation on security, but an evaluation of their activity is not possible as full reports are not available.

(2) The susceptibility of border regions to crime, together with the Schengen zone enlarge- ments, are the reason why the external EU borders are of great importance for Europe's security. In accordance to their main assumption, the ENPI CBC Programmes, created to support cross-border cooperation on the external borders of the Union, concentrate on ensuring efficient and secure borders, but this is not stated explicitly in every programme priorities. Less than half of them (7 out of 15) list priorities referring to security.

(3) The political events of the recent years have brought Poland and its borders changes in security issues. On the one hand, Poland has been getting more institutional support on security issues since its accession to the European Union. But on the other hand, changes in the permeability of the Polish borders have had some serious implications for security. First of all, lack of control at the borders with Germany, the Czech Republic, Slovakia and Lithuania is noticeable. The structure of illegal border crossings has changed significantly (while their number has remained almost the same): far more illegal border crossers are now stopped on the external EU border whereas earlier they were mostly stopped on the internal one. As a consequence, the nationality structure of illegal border crossers has changed: far more come from Poland's eastern neighbours. Secondly, the value of illegal trade, particularly the so-called trading goods, has increased significantly.

\section{References}

Anderson M., den Boer M., Cullen P., Gilmore W., RaAb C. \& Walker N. Policing the European Union. Oxford University Press. 
Albuquerque P., 2007. Shared legacies, disparate outcomes: Why American south border cities turned the tables on crime and their Mexican sisters did not. Crime, Law and Social Change, 47: 69-88.

A secure Europe in a better world: The European Security Strategy. The European Council, Brussels, 2003.

Ceccato V. \& Haining R., 2004. Crime in border regions: The Scandinavian case of Öresund, 1998-2001. Annals of the Association of American Geographers, 94 (4): 807-826.

De Ruyver B., Bruggeman W. \& Zanders P., 1993. Cross-border crime in Belgium. European Journal on Criminal Policy and Research, 1-3: 87-100.

European Neighbourhood and Partnership Instrument: CrossBorder Cooperation, Strategy Paper 2007-2013, Indicative Programme 2007-2010.

GAYLORD M., 1999. Cross-border crime and legal jurisdiction in post-colonial Hong Kong. Crime, Law and Social Change, 31: 31-48.

Guerette R. \& Clarke R., 2005. Border enforcement, organized crime, and deaths of smuggled immigrants on the United States-Mexico border. European Journal on Criminal Policy and Research, 11: 159-174.
JAMIESON R., 1999. “Contested jurisdiction border communities" and cross-border crime - the case of Akwesasne. Crime, Law and Social Change, 30: 259-272.

Junninen M. \& Aromaa K., 2000. Professional crime across the Finnish-Estonian border. Crime, Law and Social Change, 34: 319-347.

OrReniUs P. \& CoRONADO R., 2005. The effect of illegal immigration and border enforcement on crime rates along the U.S.Mexico border. Working Paper 131, Centre for Comparative Immigration Studies, University of California, San Diego.

Special Eurobarometer 290, 2008. The role of the European Union in justice, freedom and security policy areas. TNS Opinion \& Social, Belgium.

Standard Eurobarometer 72, 2009. Public opinion in the European Union. TNS Opinion \& Social, Belgium.

VAN DuYne P., 1993. Implications of cross-border crime risks in an open Europe. Crime, Law and Social Change, 20: 99111. 